\title{
ORC4 wt Allele
}

National Cancer Institute

\section{Source}

National Cancer Institute. ORC4 wt Allele. NCI Thesaurus. Code C52315.

Human ORC4 wild-type allele is located in the vicinity of 2q23.1 and is approximately 91 $\mathrm{kb}$ in length. This allele, which encodes orig in recognition complex subunit 4 protein, is involved in the initiation of chromosomal doubling. 